Egyptian Journal of Aquatic Biology \& Fisheries

Zoology Department, Faculty of Science,

Ain Shams University, Cairo, Egypt.

ISSN $1110-6131$

Vol. 23(3): $371-384$ (2019)

www.ejabf.journals.ekb.eg

\title{
Comparative Molecular Identification of Genus Dicentrarchus Using Mitochondrial Genes and Internal Transcribed Spacer Region
}

\author{
Fawzia S. Ali ${ }^{*}$, Mohamed Ismail ${ }^{2}$ and Ahmed Mamoon ${ }^{3}$ \\ 1-Aquaculture Division, National Institute of Oceanography and Fisheries (NIOF), \\ Cairo, Egypt 13621. \\ 2- Genetics Department, Faculty of Agriculture, Menoufia University, Shibin \\ El-Kom, Egypt. \\ 3- Fish Production Department, Faculty of Agriculture-Al-Azhar University, Nasr \\ City, Cairo, Egypt 11884. \\ *Corresponding author: $\underline{\mathrm{dr} \text { allam84@ hotmail.com }}$
}

\section{ARTICLE INFO \\ Article History: \\ Received: Aug. 6, 2019 \\ Accepted: Aug. 28, 2019 \\ Online: Sept. 2019}

\section{Keywords:}

Genus Dicentrarchus

DNA barcoding

Species identification

Molecular markers

COI

Cyt b

ITS

\begin{abstract}
DNA barcoding is one of the powerful DNA-based identification tools that are used for accurate identification of a species. Despite several DNA barcodes were used, the accuracy and suitability of these barcodes depend on speciesspecific variations. The current study was conducted to compare the efficiency of two mitochondrial genes to the nuclear Internal Transcribed Spacer (ITS) region in the molecular identification of genus Dicentrarchus. A total of 80 fish samples for Dicentrarchus labrax and Dicentrarchus punctatus were randomly collected from two different locations in Egypt; Alexandria and Bardawil Lagoon. All samples were morphologically characterized. For species barcoding, the ITS region was firstly employed to carry out the PCR amplifications. Additionally, two mitochondrial genes; cytochrome b (Cyt b) and cytochrome oxidase subunit I (COI) were also used for species barcoding. To evaluate the efficiency of each marker, three different approaches were used. Firstly, phylogenetic relationship was constructed between the collected samples and a reference species using each genetic marker. Secondly, Automated Barcode Gap Discovery (ABGD) method was used for each marker in order to assign the samples into presumed species without priori species assumption. Lastly, the Poisson Tree Processes (PTP) model was used which relies on Bayesian support values to delimit species on the input tree. The two species of genus Dicentrarchus exhibited nearly similar ITS sequences, leading to an ambiguous identification of the two species. However, the two mitochondrial COI and Cyt $\mathrm{b}$ genes were able to accurately distinguish between the two species. The three approaches, phylogeny, ABGD and PTP presented consistent results. Overall, COI and Cyt b outperformed ITS in assigning species accurately. Mitochondrial barcodes could provide a leading guide for fish species identification. ITS should be abandoned in favor of COI and Cyt $b$ as primary DNA barcode markers for fish species in general and Dicentrarchus genus, in particular.
\end{abstract}

\section{INTRODUCTION}

The two species of genus Dicentrarchus are close relatives in their morphological features, particularly, in the early stages of development (Merlo et al., 2010; Ali and Mamoon, 2019). The use of multiple identification tools can aid in the 
accurate identification of a species. Generally, morphological characteristics are a primary tool for species identification. Such morphological characteristics can not differentiate between two closly related species either at their early stages of development or at their adult stages (Fischer et al., 1987). In such cases, DNA-based tools are significant methods to achieve an accurate identification. DNA barcoding is one of the superior DNA-based identification tools relating to the ecology and evolution of natural systems (Kress et al., 2015). DNA barcodes are short standard parts of the genome that are amplified to identify species (Kress et al., 2015; Hebert et al., 2003). Perfect DNA barcode allows rapid, reliable, automatable, and costeffective species identification for users with little taxonomic experience (Hebert et al., 2003; Hajibabaei et al., 2005; Hebert and Gregory, 2005). Moreover, such barcodes should be easily amplified from most species in a target group using universal primers and expected to show high inter-specific divergence (Luo et al., 2011). Species identification via DNA barcoding is usually performed by comparing the unknown sequence to reference DNA barcodes, mainly via alignment searching [e.g., Basic Local Alignment Search Tool (BLAST) (Altschul et al., 1990; Altschul et $a l .$, 1997), or other known methods such as distance-based tree construction (Hebert et al., 2003), the characteristic attribute organization system (CAOS) (Hebert et al., 2004), and the back-propagation neural network (BP based species identification) (Zhang et al., 2008). Recently few methods have been developed which rely on different statistical models. For instance, ABGD (Puillandre et al., 2012) uses prior intraspecific divergence among species to infer species phylogeny, whereas, PTP uses Bayesian statistics to assign species into groups (Zhang et al., 2013).

Nuclear and mitochondrial barcodes are usually used for DNA barcoding purposes. Mitochondrial (mt) genome barcode is the most effective single-locus marker, as it possesses small size when compared to the nuclear genome. The $\mathrm{mt}$ genome carries various protein coding genes (PCGs). These PCGs encode for proteins involved in oxidative phosphorylation including cytochrome oxidase subunits, cytochrome b, NADH dehydrogenase subunits, ATPases 6 and 8, 16S and $12 \mathrm{~S}$ ribosomal RNA genes, and 22 transfer RNA genes (Luo et al., 2011). Mitochondrial genome barcodes have several desirable features that are superior to the nuclear DNA barcodes. These features include limited exposure to recombination, rapid evolution, high copy number, and lack of introns. Additionally, such features facilitate the routine amplification by polymerase chain reaction and the use of the mitochondrial molecular marker (Xu, 2005; Waugh, 2007). Among the PCGs, the cytochrome oxidase I (COI) gene locus is the most widely used DNA barcode locus for animal taxa, as it appears to fulfill the criteria for most groups (Hebert et al., 2003; Vences et al., 2005; Ward et al., 2005; Smith et al., 2005). For fish, the Fish Barcode of life initiative (FISH-BOL) campaign, (Ward et al., 2009) has utilized the sequence of the COI gene "648 bp region" for more than 100,000 specimens representing more than 10,000 species. With these resources, DNA barcoding has embloyed COI to trace fish species in the Egyptian aqua-feed formulations (Galal-Khallaf et al., 2016), differentiate between members of the Sparidae species (Armani et al., 2015; Abbas et $a l ., 2017)$, and verify the labels on seafood products commercialized in Southern Brazil marketplaces (Carvalho et al., 2015), and other studies on fish in Europe (Di Pinto et al., 2013; Vandamme et al., 2016; Helyar et al., 2014). Cytochrome b (Cyt b) is another mitochondrial gene widely used for animal species differentiation (Tsai et al., 2007). This gene is also used for the dentification of $\sim 50$ European marine fish species (Kochzius et al., 2010); and fish mislabeling in Italy (Filonzi et al., 2010). D. 
labrax was identified using two mitochondrial genes barcodes, Cyt b and COI and microarrays (Kochzius et al., 2010).

On the other hand, the eukaryotic rRNA cistron consists typically of the 18S, 5.8S linked to 25-28S rRNA genes separated by external and internal transcribed spacer. Two internal spacers can separate between 18S, 5.8S rRNA genes (ITS1) and 5.8S, 28S rRNA gene (ITS2) (Hillis and Dixon, 1991). The two spacers, with the $5.8 \mathrm{~S}$ gene, are commonly referred to as "ITS region". The $18 \mathrm{~S}$ nuclear ribosomal small subunit rRNA gene (SSU) is commonly used as a DNA barcode in species identification and taxonomy (Fonseca et al., 2014; Šlapeta et al., 2005; Lie et al., 2014; Zhan et al., 2014). The 28S nuclear ribosomal large subunit rRNA gene can discriminate species in isolation or integrated with ITS. Such ITS region is variable in the rRNA cistron among genera and species and its sequence comparisons are popular tools for phylogenetic analysis and populations studies (Paul, 2001). Similarly, ITS region is used in the barcoding of fungi (Dentinger et al., 2011; Stern et al., 2012). However, the direct use of ITS region, ITS1 and ITS2 as a universal barcode for barcoding fish species is not common and COI is still the primary and the most efficient barcode used for fish identification. In addition, there are many conflicting views about the exact ITS locus that should be used as a barcode, (complete ITS region, ITS1 or ITS2) (Yao et al., 2010; Wang et al., 2015; Tahir et al., 2018). ITS2 is known to be a satisfactory barcode for medicinal plants families identification such as Fabaceae and Poaceae (Tahir et al., 2018), and it is more effective than the complete ITS region for barcoding of plants (Han et al., 2012). On the other hand, according to (Wang et al., 2015; Yao et al., 2010), ITS1 over performed ITS2 in barcoding number of eukaryotic taxa using sequences from the Genebank on the bases of the sequences CG content. The sequence of ITS4 primer described by White et al. (1990) has been modified by Elmosallamy et al. (2015) to be more efficient in amplifying the ITS region in animals (ITS4-A). Using the latter modified primer with ITS1 primer (White et al., 1990), helped in successful amplification of ITS region in Posthodiplostomum sp., directly from Nile Tilapia (Oreochromis niloticus) that acts as its second host. Therefore, it was promising to apply the modified primer (ITS4-A) for fish identification. Furthermore, there are limited number of studies that compared fish barcodes; for example (Kochzius et al., 2010) used mitochondrial barcodes to confirm the efficiency of COI and Cyt b compared to $16 \mathrm{~S}$ rRNA in fish species identification.

For the previously mentioned reasons, the objective of the herein study is to conduct a comparison between the efficiency of the mitochondrial Cyt b and COI, and the nuclear ITS region for identification of genus Dicentrarchus to specify an accurate and reliable barcode for fish species identification.

\section{MATERIALS AND METHODS}

\section{Samples collection:}

Fifty-five samples of Dicentrarchus labrax, and twenty-five samples of $D$. punctatus were collected in July 2016 from, Alexandria city and Bardawil Lagoon in Egypt with approximate coordinates $31^{\circ} 11^{\prime} 26^{\prime \prime} \mathrm{N}, 33^{\circ} 09^{\prime} 44^{\prime \prime} \mathrm{E}$ and $31^{\circ} 12^{\prime} 56^{\prime \prime} \mathrm{N}$ $29^{\circ} 57^{\prime} 19^{\prime \prime} \mathrm{E}$, respectively. The samples were morphologically identified by their external features described by the FishBase (Whitehead et al., 1986; White et al., 1990).

\section{Molecular examination:}

DNA extraction: 
The molecular examination was performed at the Genetics Laboratories of the National Institute of Oceanography and Fisheries (NIOF, Egypt), between July and November 2016. After examining the morphological characteristics of all samples, caudal fins of $D$. labrax samples

were preserved in $-20^{\circ} \mathrm{C}$ in absolute ethanol. DNA was extracted as described by Asahida et al. (1996) with some modifications as described by (Ali et al., 2017). Briefly, $700 \mu \mathrm{L}$ of TNES-Urea Buffer and $30 \mu \mathrm{L}$ of proteinase $\mathrm{K}(10 \mathrm{mg} / \mathrm{mL})$ were added. Phenol-Chloroform-Isoamy Alcohol (25:24:1) was added twice with an equal volume and centrifuged. Finally, DNA precitation was done using two volumes of ice cold $100 \%$ EtOH. DNA pellets were dissolved in Tris EDTA (TE) buffer. DNA concentrations were spectrophotometrically quantified (eppendorf, Hamburg, Germany) and stored at $4^{\circ} \mathrm{C}$ for further analysis.

\section{PCR amplification for ITS region:}

The amplifications of the ITS region and other target regions (COI, Cyt b) were performed in a $30 \mu \mathrm{L}$ volume using BIOLINE master mix (2X My Taq ${ }^{\mathrm{TM}} \operatorname{Red}$ Mix) according to the manufacturer's instructions. PCR mixture contained $15 \mu \mathrm{L}$ BIOLINE master mix, $2 \mu \mathrm{L}$ DNA template (final concentration $20 \mathrm{mg}$ ), and $1 \mu \mathrm{L}$ of each primer (final concentration $0.25 \mu \mathrm{M}$ ). The ITS region amplification and sequencing were performed using ITS1 forward primer described by White et al. (1990) and ITS4-A reverse primer modified by Elmosallamy et al. (2015) Table 1. PCR was performed using BIO-RAD PCR System (BIO-RAD, T100 96-well Thermal Cycler, USA). Amplifications for ITS region were performed as followed: i) initial denaturation for 4 min at $95^{\circ} \mathrm{C}$, ii) 35 cycles of $94^{\circ} \mathrm{C}$ for $50 \mathrm{~s}, 55^{\circ} \mathrm{C}$ for $50 \mathrm{~s}$, and $72^{\circ} \mathrm{C}$ for $90 \mathrm{~s}$, and iii) final extension for $7 \mathrm{~min}$ at $72^{\circ} \mathrm{C}$.

\section{PCR amplification for mitochondrial genes:}

The target region of mitochondrial gene COI was amplified using the primer pairs described by Ward et al. (2005), Table 1. Amplifications were performed using the following thermal profile: i) initial denaturation for 4 min at $95^{\circ} \mathrm{C}$, ii) 30 cycles of $94^{\circ} \mathrm{C}$ for $30 \mathrm{~s}, 57^{\circ} \mathrm{C}$ for $30 \mathrm{~min}$, and $72^{\circ} \mathrm{C}$ for $30 \mathrm{~s}$, and iii) final extension at $72^{\circ} \mathrm{C}$ for 7 min. The target region of mitochondrial gene, Cyt $\mathrm{b}$ was amplified using the primer pairs described by Patarnello et al. (1993), Table 1. Amplifications were performed with the following thermal profile: i) initial denaturation at $95^{\circ} \mathrm{C}$ for $4 \mathrm{~min}$, ii) 35 cycles of $94^{\circ} \mathrm{C}$ for $30 \mathrm{~s}, 56^{\circ} \mathrm{C}$ for $50 \mathrm{~min}$, and $72^{\circ} \mathrm{C}$ for $50 \mathrm{~s}$, and iii) $7 \mathrm{~min}$ final extension at $72^{\circ} \mathrm{C}$. Five $\mu \mathrm{L}$ of the PCR products were loaded to $2.5 \%$ agarose gel containing $2 \mu \mathrm{L}$ of Eth $\mathrm{Br}(100 \mathrm{mg} / \mathrm{mL})$, and electrophoresed. The acceptable bands sizes ( 750 base pairs) were purified using the Gene JET Gel Extraction Kit (Catalog no. K0961, Thermo Scientific). The purified PCR products of all samples were then sequenced using the Applied Bio-systems 3500 Genetic Analyzer Sequencer (Hitachi, Japan).

Table 1. Primer sequences for the three markers used in the study.

\begin{tabular}{|c|c|c|}
\hline Primer code & Primer sequence $\left(5^{\prime}-3^{\prime}\right)$ & Reference \\
\hline ITS1-F & CTTGGTCATTTAGAGGAAGTAA & (White et al., 1990; \\
\hline ITS4-A-R & TGCCGGTATTTAGCCTTAGATGGAG & Elmosallamy et al., 2015) \\
\hline COI-Fish-F & TTCTCAACTAACCAYAAAGAYATYGG & (Ward et al., 2005) \\
\hline COI-Fish-R & TAGACTTCTGGGTGGCCRAARAAYCA & \\
\hline Cytb-F & TCGCAAATCATGCACTTGTT & (Patarnello et al., 1993) \\
\hline Cytb-R & CСССТCAAATCCACTGAACT & \\
\hline
\end{tabular}




\section{Sequence alignment and data analysis:}

Prior to sequence analysis, the obtained sequences for each studied marker were compared to the available reference sequences on GenBank using BLAST algorithm available from http://www.ncbi.nlm.nih.gov/blast. A representative sample of the obtained sequences were then deposited in GenBank database (accession numbers LC387524- LC387528 for ITS region; LC387519- LC387523, for COI, and LC384918- LC384922 for Cyt b). The obtained sequences were aligned and edited using BioEdit (Hall, 1999). Following sequence alignment, consensus sequences from forward and reverse sequences were obtained and then contigs were assembled across each species for each studied marker using BioEdit to be used in phylogenetic reconstruction. For each studied marker, a reference sequence, and an out-group sequence (Oreochromis niloticus) were retrieved from NCBI for further inclusion in the data analysis (Table 2). Three independent approaches were employed to determine the efficiency of ITS, COI, and Cyt b markers in the identification of Dicentrarchus species. First, genetic relationship among the studied species and their reference sequence was obtained based on Kimura 2-parameter (K2P) genetic distance (Kimura, 1980) as implemented in MEGA X (Kumar et al., 2018). Phylogenetic relationship among species using contig sequences was then obtained according to unweighted pair group method with arithmetic mean (UPGMA) as implemented in MEGA $X$. The relative robustness of individual branches was estimated by bootstrapping (Felsenstein, 1985), in which 10000 bootstrapped trees were generated from the re-sampled data. Second, ABGD method was used (Puillandre et al., 2012) with the ITS, Cyt b, and COI datasets for all species sequences (80 samples). This method uses a repetitive process to assign sequences into presumed species without a priori species assumption even when two species distributions overlap (Puillandre et al., 2012). The ABGD was used with K2P model to calculate pairwise distances (K80 option with TS/TV $=2.0)$, 10 recursive steps, $\mathrm{X}$ (relative gap width) $=1.5$ and the remaining parameters set to default values (Pmin= 0.001, Pmax $=0.1, \mathrm{Nb}$ bins $=20$ ). Prior distribution $(P)$ values obtained from ABGD were plotted using SigmaPlot (Systat Software, San Jose, CA) which were adapted from original program output. Third, the PTP model was used (Zhang et al., 2013). This approach uses Bayesian support values (BS) to delimited species on the input tree; the higher BS values on any given node support the notion that all sequences descendent from this node are more likely from one species (Zhang et al., 2013).

Table 2. Reference and out-group sequences for the three markers used in the study.

\begin{tabular}{|c|c|c|c|c|}
\hline $\begin{array}{c}\text { Molecular } \\
\text { marker }\end{array}$ & Reference sequence & $\begin{array}{c}\text { Gene Bank } \\
\text { accession number }\end{array}$ & $\begin{array}{l}\text { Out-group } \\
\text { sequence }\end{array}$ & $\begin{array}{c}\text { Gene Bank } \\
\text { accession number }\end{array}$ \\
\hline ITS & $\begin{array}{l}\text { D. } \text { labrax }(\operatorname{Ref})^{*} \\
\text { D. punctatus }(\operatorname{Ref})\end{array}$ & $\begin{array}{l}\text { HQ291516.1 } \\
\text { HM014387.1 }\end{array}$ & & MF460358.1 \\
\hline COI & $\begin{array}{l}\text { D. labrax (Ref) } \\
\text { D. punctatus }(\text { Ref })\end{array}$ & $\begin{array}{l}\text { KY176457.1 } \\
\text { LC317272.1 }\end{array}$ & Oreochromis niloticus & MG428624.1 \\
\hline Cyt b & $\begin{array}{l}\text { D. labrax }(\operatorname{Ref}) \\
\text { D. punctatus }(\text { Ref })\end{array}$ & $\begin{array}{l}\text { KU168693.1 } \\
\text { EU107385.1 }\end{array}$ & & MH041447.1 \\
\hline
\end{tabular}

Ref indicates reference sequence.

\section{RESULTS}

\section{Molecular identification:}

All tested samples showed positive PCR amplifications for the ITS region, and COI, Cyt $\mathrm{b}$ mitochondrial genes. The amplification of the target regions in the two mitochondrial genes produced $610 \mathrm{bp}$ and $370 \mathrm{bp}$ fragments for COI and Cyt b, 
respectively. BLAST analysis of all sequences of the morphologically identified $D$. punctatus and D. labrax samples confirmed $100 \%$ match with both D. Labrax and D. punctatus species. The identity ranged between $97 \%$ and $100 \%$ with the maximum identity of $99 \%$ and $100 \%$ for COI and Cyt b sequences, respectively. However, the analysis of ITS fragment ( $900 \mathrm{bp}$ ) showed inconsistent results for the species identification. These results came in agreement with the aligned ITS sequences that showed $97 \%$ - 100\% similarity with both species (D. punctatus and D. labrax), during BLAST searches. Moreover, by retrieving and aligning the submitted ITS sequences for D. punctatus and D. labrax from the GenBank database, no observed differences were detected among the ITS sequences. Following sequence alignment, slight differences were observed between the studied and the reference ITS sequences of D. labrax and D. punctatus indicating that, this barcode region was not able to differentiate between these two closely related species. On the other hand, clear differences were found between the COI and Cyt b sequences for two species on the GenBank database.

\section{Phylogeny, barcocde gap discovery and Bayesian analysis:}

Using ITS marker, the phylogenetic relationship of D. punctatus, D. labrax and its reference sequences based on $\mathrm{K} 2 \mathrm{P}$ genetic distance clearly showed one main group (Fig. 1A). This group included D. labrax, D. labrax (Ref), D. punctatus and D. punctatus (Ref). On the other hand, when using COI and Cyt b markers to infer species phylogeny, both markers showed similar grouping pattern with two distinct groups (Fig. 1B) and (Fig. 1C) for COI and Cyt b, respectively. In both phylogenetic trees, D. labrax and D. labrax (Ref) formed one group while D. punctatus and D. punctatus (Ref) formed a second group. Alike, ABGD analysis was able to infer two putative groups according to the ITS and COI and three putative groups according to Cyt b (Fig. 2).

However, based on ITS marker the, assignment of studied species into two putative groups were not clear. For instance, at number of inferred groups $=2$, prior intraspecific divergence $(P=0.005)$ (Fig. $2 \mathrm{~A})$, all $55 \mathrm{D}$. labrax sequences, $14 \mathrm{D}$. punctatus sequences, D. labrax (Ref) and D. punctatus (Ref) sequences were assigned to one group whereas the remaining $11 \mathrm{D}$. punctatus sequences were assigned to the other putative group, Table 3. On the other hand, COI and Cyt b showed consistent results; D. labrax sequences and its D. labrax (Ref) sequence, were assigned to one group while D. punctatus and D. punctatus (Ref) were assigned into the second group. However using Cyt b, only 17 of D. labrax sequences were assigned into sparet group (Table 3).

Table 3: Number of identified groups and its assigned sequences according to ABGD.

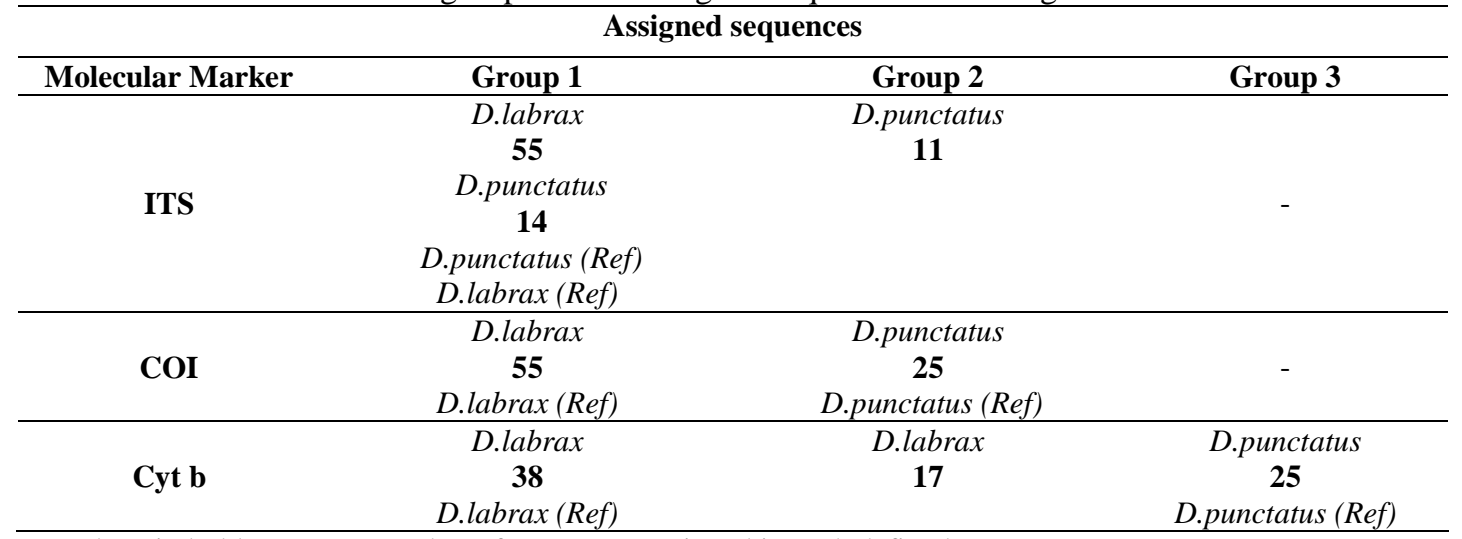

\footnotetext{
Numbers in bold represent number of sequences assigned in each defined group.
}

- Not defined. 
(A)

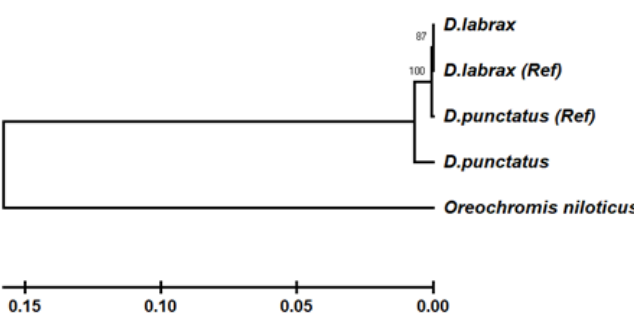

(B)
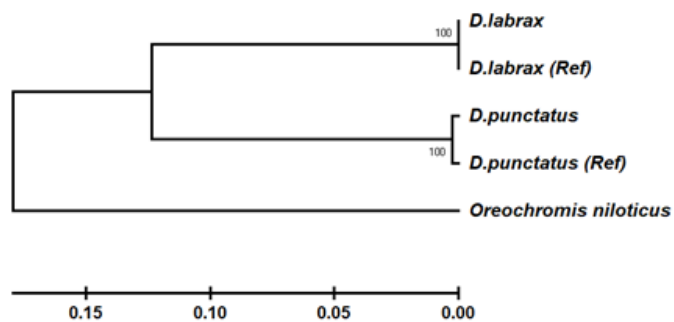

(C)

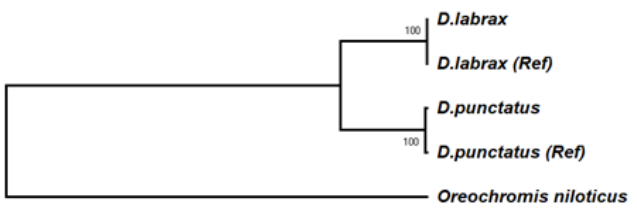

\begin{tabular}{cccccc}
1 & 1 & 1 & 1 & 1 & \\
\hline 0.55 & 0.44 & 0.33 & 0.22 & 0.11 & 0.00
\end{tabular}

Fig. 1: Phylogenetic relationship of Dicentrarchus species and its outgroup using UPGMA method: (A) ITS, (B) COI, and (C) Cyt b.
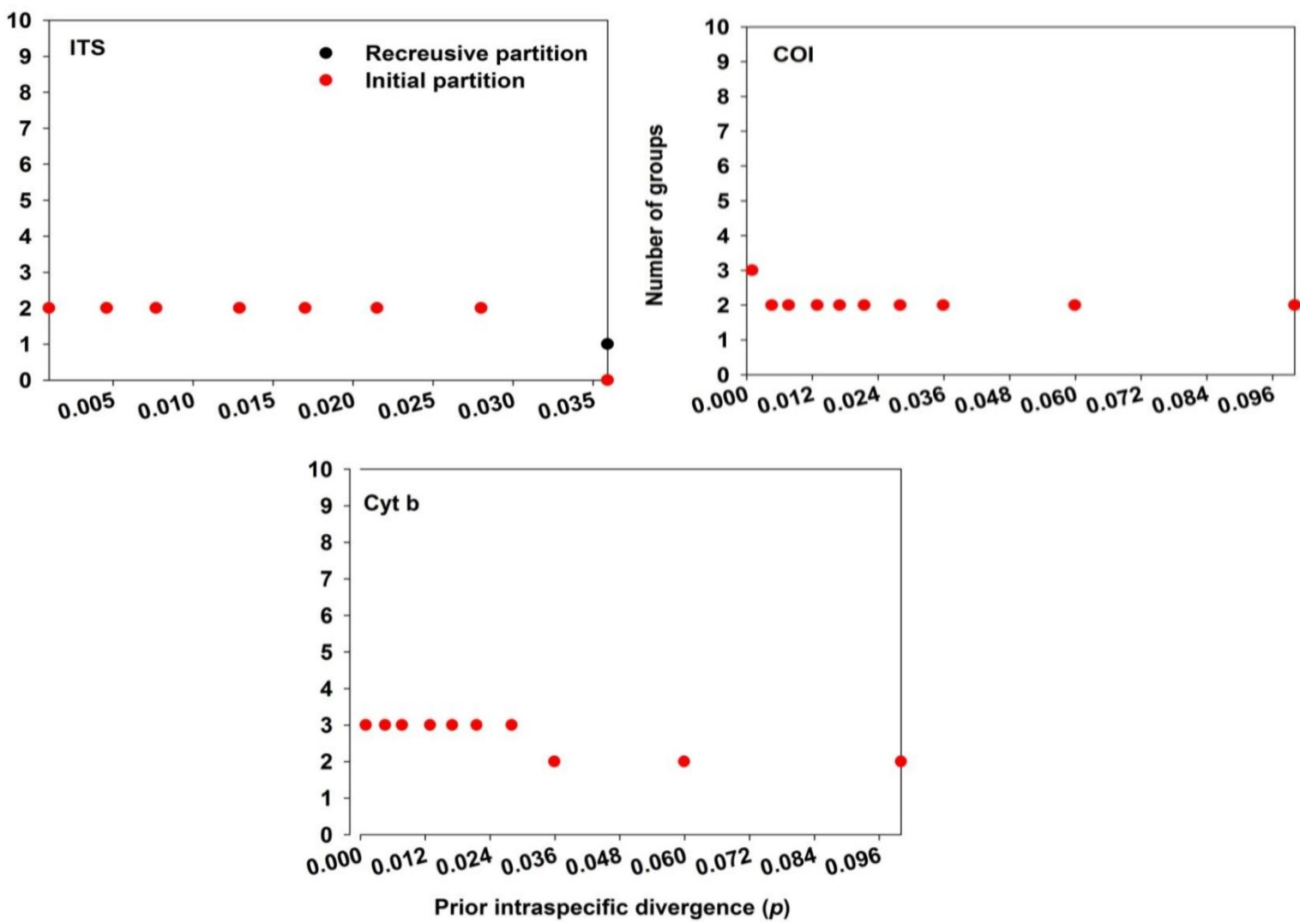

Fig. 2: The number of groups inferred from ABGD analysis according to prior intraspecific divergence $(P)$

According to PTP model and based on ITS marker, D. labrax and D. punctatus sequences and their reference sequences were assigned into six groups (Table 4). The studied sequences of both species were assigned randomly to the identified groups. For instance in group 5 , a total of $18 \mathrm{D}$. labrax sequences were assigned into one group along with D. punctatus (Ref) with BS value of 53\%. Contrarily, consistent results were obtained using COI and Cyt b where PTP was able to assign all $55 D$. labrax sequences and its reference sequence D. labrax (Ref) into one group and all 25 
D. punctatus sequences and its reference sequence D. punctatus (Ref) into a second group with BS value of $83 \%$ and $100 \%$ COI and Cyt b, respectively (Table 4).

Table 4: Number of identified groups and its assigned sequences according to PTP.

\begin{tabular}{|c|c|c|c|c|c|c|}
\hline & \multicolumn{6}{|c|}{ Assigned sequences } \\
\hline $\begin{array}{l}\text { Molecular } \\
\text { Marker }\end{array}$ & Group 1 & Group 2 & Group 3 & Group 4 & Group 5 & Group 6 \\
\hline ITS & $\begin{array}{c}\text { D.punctatus } \\
(0.920)^{*} \\
\mathbf{1 3}\end{array}$ & $\begin{array}{l}\text { D.punctatus } \\
(0.563) \\
\mathbf{1 2}\end{array}$ & $\begin{array}{c}\text { D.labrax } \\
(0.284) \\
\mathbf{1 6}\end{array}$ & $\begin{array}{c}\text { D.labrax (Ref) } \\
\quad(0.284)\end{array}$ & $\begin{array}{c}\text { D.labrax } \\
\mathbf{1 8} \\
\text { D.punctatus }(\text { Ref }) \\
(0.535) \\
\end{array}$ & $\begin{array}{c}\text { D.labrax } \\
(0.535) \\
\mathbf{2 1}\end{array}$ \\
\hline COI & $\begin{array}{c}\text { D.labrax } \\
\mathbf{5 5} \\
\text { D.labrax }(\text { Ref }) \\
(0.838) \\
\end{array}$ & $\begin{array}{c}\text { D.punctatus } \\
\mathbf{2 5} \\
\text { D.punctatus }(\text { Ref }) \\
(1.000) \\
\end{array}$ & - & - & - & - \\
\hline Cyt b & $\begin{array}{c}\text { D.labrax } \\
\mathbf{5 5} \\
\text { D.labrax }(\text { Ref }) \\
(0.838) \\
\end{array}$ & $\begin{array}{c}\text { D.punctatus } \\
\mathbf{2 5} \\
\text { D.punctatus (Ref) } \\
(1.000) \\
\end{array}$ & - & - & - & - \\
\hline
\end{tabular}

*Bayesian support values associated with PTP.

Numbers in bold represent number of sequences assigned in each defined group.

Not define.

\section{DISCUSSION}

Overall, the primer combinations used for amplifying the target regions of different barcodes were successful. The ITS4-A primer (Elmosallamy et al., 2015) increased the efficiency of amplification quality and specificity at standard annealing temperature $\left(55^{\circ} \mathrm{C}\right)$. However, the performance of the mitochondrial genes (COI, Cyt b) and ITS as barcode markers were different for the identification of Dicentrarchus species. Based on sequence similarity, both mitochondrial genes COI and Cyt b were accuarte in distinguishing between the two species. Such identification was supported by the results of the morphological examination and the analysis of the employed approaches; PTP, ABGD and the classical phylogenetic approach. These results are in agreement with similar findings in different animal taxa barcoding using COI (Smith et al., 2005); in Australian fish, (Ward et al., 2005); in Canadian fish, (Hubert et al., 2008); in Taiwanese fish, (Bingpeng et al., 2018). Collectivley, these reports display the efficiency of COI gene barcode for identification of fish species. Additionally, Cyt b barcode region was successfully used in barcoding the animal taxa in general (Tsai et al., 2007) and fish barcoding in particular (Kochzius et al., 2010; Filonzi et al., 2010). The recorded efficiency of these mitochondrial barcodes could be explained on the basis of their features that make them suitable markers for fish barcoding which include limited exposure to recombination, lack of introns, and rapid evolution (Xu, 2005; Waugh, 2007).

On the other hand, Using the classical phylogenetic approach based on genetic distance, the ITS region was not able to accurately differentiate between D. labrax and D. punctatus. Additionally, using both ABGD and PTP which rely on two different analytical models, ITS showed weakness in the assignment of species into its specific group (Tables $2 \& 3$ ). Liu et al. (2012) compared the efficiency of the ITS region as a multiple-copy region to the single-copy ribosomal protein S7 gene intron 1 (rpS7), and they proved the effectiveness of the RPS- ${ }^{\text {st }}$ intron as a successful barcode for Coilia nasus (Clupeiformes: Engraulidae).

The retrieved ITS sequences covered a partial sequence of $18 \mathrm{~S}$ ribosomal RNA gene, the complete sequence of internal transcribed spacer 1 (ITS1), and a partial 
sequence of 5.8S ribosomal RNA gene (Merlo et al., 2010). Several studies had reported the conserved nature of both $18 \mathrm{~S}$ and $5.8 \mathrm{~S}$ regions sequences (Dentinger et al., 2011; Bulygin et al., 2003; Pánek et al., 2013). This theory can explain the inefficiency of the amplified sequence to distinguish two closely related species (Merlo et al., 2010). The presence of these invariable sequences in the amplified region can affect the efficiency of this region as a barcode for most species. Whereas, the primer pairs employed in this study amplified the ITS region (ITS1, 5.8S rDNA, and ITS2) which is considered the most hypervariable region in the DNA cistron (Paul, 2001). However, this variable region could not perform as an accurate barcode to identify D. labrax. These findings probably related to the presence of the invariable 5.8S DNA sequence in this region, that can decrease the comparative divergence, and increase sequence similarity between individuals (Dentinger et al., 2011). Even though ITS barcode marker is considered the best barcode for most fungi (Dentinger et al., 2011; Stern et al., 2012); it failed to accurately distinguish fish species.

Generally, the success of DNA barcoding technique for species identification relies on two main conditions, first; the selection of a suitable barcode target and, second; the previous knowledge of reference sequences for specific species (Ward et $a l ., 2009)$. The establishment of an online database can improve the reliability and facilitate the use of barcoding technique (Ekrem et al., 2007). For example, the FISHBOL campaign (Ward et al., 2009), has already collected the COI sequence for more than 10,000 species. Using these reference sequences, COI based DNA barcoding has been extensively used to barcode fish species (Hubert et al., 2008), study different fish populations (Wang et al., 2017), and to evaluate the fish product mislabeling (Helyar et al., 2014; Vandamme et al., 2016).

\section{CONCLUSION}

Our results revealed that the mitochondrial barcode markers (COI and Cyt b) are more constant and over performed ITS region in the molecular identification of $D$. labrax. We suggest applying COI and/or Cyt b compared to ITS region which has very limited power as barcode in the molecular identification of the fish species. Nonetheless, more studies are encouraged where more samples to be included in order to further support this suggestion.

\section{ACKNOWLEDGEMENT}

The authors would like to thank Dr. Mohammed Farouk for help in manuscript revision.

\section{REFERENCES}

Abbas, E. M.; Soliman, T.; El-Magd, M. A.; Farrag, M. M.; Ismail, R. F. and Kato, M. (2017). Phylogeny and DNA Barcoding of the Family Sparidae Inferred from Mitochondrial DNA of the Egyptian Waters. J. Fish. Aquat. Sci., 12 (2): 73-81. https://doi.org/10.3923/jfas.2017.73.81.

Ali, F. S.; Nazmi, H. M.; Abdelaty, B. S.; El-Far, A. M. and Goda, A. M. (2017). Genetic improvement of farmed Nile tilapia (Oreochromis niloticus) through selective breeding in Egypt. Int. J. Fish. Aquat. Stud., 5 (6): 395-401. 
Ali, F. S. and Mamoon, A. (2019). Population genetic studies of genus Dicentrarchus reveal loss of genetic diversity in Egyptian waters. Reg. Stud. Mar. Sci., 31. https://doi.org/10.1016/j.rsma.2019.100783.

Altschul, S. F.; Gish, W.; Miller, W.; Myers, E. W. and Lipman, D. J. (1990). Basic local alignment search tool. J. Mol. Biol., 215 (3): 403-410. https://blast.ncbi.nlm.nih.gov/Blast.cgi.

Altschul, S. F.; Madden, T. L.; Schäffer, A. A.; Zhang, J.; Zhang, Z.; Miller, W. and Lipman, D. J. (1997). Gapped BLAST and PSI-BLAST: a new generation of protein database search programs. Nucleic Acids Res., 25 (17): 3389-3402. https://doi.org/10.1093/nar/25.17.3389.

Armani, A.; Tinacci, L.; Xiong, X.; Castigliego, L.; Gianfaldoni, D. and Guidi, A. (2015). Fish species identification in canned pet food by BLAST and Forensically Informative Nucleotide Sequencing (FINS) analysis of short fragments of the mitochondrial 16s ribosomal RNA gene (16S rRNA). Food Control 50: 821-830. https://doi.org/10.1016/j.foodcont.2014.10.018.

Asahida, T.; Kobayashi, T.; Saitoh, K. and Nakayama, I. (1996). Tissue preservation and total DNA extraction form fish stored at ambient temperature using buffers containing high concentration of urea. Fish. Sci., 62 (5): 727-730. https://doi.org/10.2331/fishsci.62.727.

Bingpeng, X.; Heshan, L.; Zhilan, Z.; Chunguang, W.; Yanguo, W. and Jianjun, W. (2018). DNA barcoding for identification of fish species in the Taiwan Strait. PLoS One., 13 (6): e0198109. https://doi.org/10.1371/journal.pone.0198109.

Bulygin, K. N.; Meshchaninova, M. I.; Ven'yaminova, A. G.; Graifer, D. M.; Frolova, L. Y. and Karpova, G. G. (2003). Highly Conserved Region 1816-1831 of the 18S Ribosomal RNA Is Close to the First Nucleotide of the A-Site Codon in Elongation and Termination of Translation. Mol. Biol., 37 (3): 415-420. https://doi.org/10.1023/A:1024291428015.

Carvalho, D. C.; Palhares, R. M.; Drummond, M. G. and Frigo, T. B. (2015). DNA Barcoding identification of commercialized seafood in South Brazil: a governmental regulatory forensic program. Food Control, 50: 784-788. https://doi.org/10.1016/j.foodcont.2014.10.025.

Dentinger, B. T.; Didukh, M. Y. and Moncalvo, J.-M. (2011). Comparing COI and ITS as DNA barcode markers for mushrooms and allies (Agaricomycotina). PLoS One, 6 (9): e25081. https://doi.org/10.1371/journal.pone.0025081.

Di Pinto, A.; Di Pinto, P.; Terio, V.; Bozzo, G.; Bonerba, E.; Ceci, E. and Tantillo, G. (2013). DNA barcoding for detecting market substitution in salted cod fillets and battered cod chunks. Food Chem., 141 (3): 1757-1762. https://doi.org/10.1016/j.foodchem.2013.05.093.

Ekrem, T.; Willassen, E. and Stur, E. (2007). A comprehensive DNA sequence library is essential for identification with DNA barcodes. Mol. Phylogen. Evol., 43 (2): 530-542. https://doi.org/10.1016/j.ympev.2006.11.021.

Elmosallamy, M. M.; Salah, F.; Ramirez, A. S. and Rashed, M. A. (2015). of Conference. Molecular identification of newly reported Posthodiplostomum sp. from Oreochromis niloticus in Nile River, Egypt. Paper read at XI International Interdisciplinary Scientific Research Congress, at Santo Domingo, Dominican Republic.

Felsenstein, J. (1985). Confidence limits on phylogenies: an approach using the bootstrap. Evolution, 39 (4): 783-791. https://doi.org/10.2307/2408678. 
Filonzi, L.; Chiesa, S.; Vaghi, M. and Marzano, F. N. (2010). Molecular barcoding reveals mislabelling of commercial fish products in Italy. Food Res. Int., 43 (5): 1383-1388. https://doi.org/10.1016/j.foodres.2010.04.016.

Fischer, W.; Bauchot, M. L. and Schneider, M. (1987). Fiches FAO d'identification des espèces pour le besoins de la pèche. (Révision 1). Méditerranée et mer Noir zone de pèche 37. Rome: FAO. https://doi.org/10.1016/j.tree.2014.10.008.

Fonseca, V. G.; Carvalho, G. R.; Nichols, B.; Quince, C.; Johnson, H. F.; Neill, S. P.; Lambshead, J. D.; Thomas, W. K.; Power, D. M. and Creer, S. (2014). Metagenetic analysis of patterns of distribution and diversity of marine meiobenthic eukaryotes. Global Ecol. Biogeogr., 23 (11): 1293-1302. https://doi.org/10.1111/geb.12223.

Galal-Khallaf, A.; Osman, A. G.; Carleos, C. E.; Garcia-Vazquez, E. and Borrell, Y. J. (2016). A case study for assessing fish traceability in Egyptian aquafeed formulations using pyrosequencing and metabarcoding. Fish. Res., 174: 143150. https://doi.org/10.1016/j.fishres.2015.09.009.

Hajibabaei, M.; Ivanova, N. V.; Ratnasingham, S.; Dooh, R. T.; Kirk, S. L.; Mackie, P. M. and Hebert, P. D. (2005). Critical factors for assembling a high volume of DNA barcodes. Philos. Trans. R. Soc. Lond., B, Biol. Sci., 360 (1462): 19591967. https://doi.org/10.1098/rstb.2005.1727.

Hall, T. A. (1999). BioEdit: a user-friendly biological sequence alignment editor and analysis program for Windows 95/98/NT. In Nucleic Acids Symp. Ser., 95-98: [London]: Information Retrieval Ltd., c1979-c2000.

Han, J.; Zhu, Y.; Chen, X.; Liao, B.; Yao, H.; Song, J.; Chen, S. and Meng, F. (2012). The short ITS2 sequence serves as an efficient taxonomic sequence tag in comparison with the full-length ITS. BioMed Res. Int., 13: 13-20. https://doi.org/10.1155/2013/741476.

Hebert, P. D.; Cywinska, A. and Ball, S. L. (2003). Biological identifications through DNA barcodes. Proc. R. Soc. Lond., B, Biol. Sci., 270 (1512): 313-321. https://doi.org/10.1098/rspb.2002.2218

Hebert, P. D. and Gregory, T. R. (2005). The promise of DNA barcoding for $\begin{array}{lllll}\text { taxonomy. } & \text { Syst. } & \text { Biol., } & 54 & \text { (5): }\end{array}$ https://doi.org/10.1080/10635150500354886.

Hebert, P. D.; Penton, E. H.; Burns, J. M.; Janzen, D. H., and Hallwachs, W. (2004). Ten species in one: DNA barcoding reveals cryptic species in the neotropical skipper butterfly Astraptes fulgerator. Proc. Natl. Acad. Sci. U.S.A., 101 (41): 14812-14817. https://doi.org/10.1073/pnas.0406166101.

Helyar, S. J.; Lloyd, H. a. D.; de Bruyn, M.; Leake, J.; Bennett, N. and Carvalho, G. R. (2014). Fish product mislabelling: failings of traceability in the production chain and implications for illegal, unreported and unregulated (IUU) fishing. PLoS One 9 (6): e98691. https://doi.org/10.1371/journal.pone.0098691.

Hillis, D. M. and Dixon, M. T. (1991). Ribosomal DNA: molecular evolution and phylogenetic inference. Q. Rrev. Biol., 66 (4): 411-453. https://doi.org/10.1086/417338.

Hubert, N.; Hanner, R.; Holm, E.; Mandrak, N. E.; Taylor, E.; Burridge, M.; Watkinson, D.; Dumont, P.; Curry, A.; Bentzen, P.; Zhang, J.; April, J. and Bernatchez, L. (2008). Identifying Canadian Freshwater Fishes through DNA Barcodes. PLoS One, 3 (6): e2490. https://doi.org/10.1371/journal.pone.0002490.

Kimura, M. (1980). A simple method for estimating evolutionary rates of base substitutions through comparative studies of nucleotide sequences. J. Mol. Evol., 16 (2): 111-120. 
Kochzius, M.; Seidel, C.; Antoniou, A.; Botla, S. K.; Campo, D.; Cariani, A.; Vazquez, E. G.; Hauschild, J.; Hervet, C. and Hjörleifsdottir, S. (2010). Identifying fishes through DNA barcodes and microarrays. PLoS One, 5 (9): e12620. https://doi: 10.1371/journal.pone.0012620.

Kress, W. J.; García-Robledo, C.; Uriarte, M., and Erickson, D. L. (2015). DNA barcodes for ecology, evolution, and conservation. Trends Ecol. Evol., 30 (1): 25-35. https://doi.org/10.1016/j.tree.2014.10.008.

Kumar, S.; Stecher, G.; Li, M.; Knyaz, C. and Tamura, K. (2018). MEGA X: Molecular Evolutionary Genetics Analysis across Computing Platforms. Mol. Biol. Evol., 35 (6): 1547-1549. https://doi.org/10.1007/BF01731581.

Lie, A. A.; Liu, Z.; Hu, S. K.; Jones, A. C.; Kim, D. Y.; Countway, P. D.; AmaralZettler, L. A.; Cary, S. C.; Sherr, E. B. and Sherr, B. F. (2014). Investigating microbial eukaryotic diversity from a global census: insights from a comparison of pyrotag and full-length sequences of $18 \mathrm{~S}$ rRNA gene sequences. Appl. Environ. Microbiol.: AEM. 00057-14. https://doi.org/10.1128/AEM.00057-14.

Liu, D.; Guo, H.-Y.; Tang, W.-Q. and Yang, J. Q. (2012). Comparative evolution of S7 Intron 1 and ribosomal internal transcribed spacer in Coilia nasus (Clupeiformes: Engraulidae). Int. J. Mol. Sci., 13 (3): 3085-3100. https://doi:10.3390/ijms13033085.

Luo, A.; Zhang, A.; Ho, S. Y.; Xu, W.; Zhang, Y.; Shi, W.; Cameron, S. L. and Zhu, C. (2011). Potential efficacy of mitochondrial genes for animal DNA barcoding: a case study using eutherian mammals. BMC Genomics, 12 (1): 84. https://doi.org/10.1186/1471-2164-12-84.

Merlo, M. A.; Cross, I.; Chairi, H.; Manchado, M. and Rebordinos, L. (2010). Analysis of three multigene families as useful tools in species characterization of two closely-related species, Dicentrarchus labrax, Dicentrarchus punctatus and their hybrids. Genes Genet. Syst., 85 (5): 341-349. https://doi.org/10.1266/ggs.85.341.

Pánek, J.; Kolář, M.; Vohradský, J. and Shivaya Valášek, L. (2013). An evolutionary conserved pattern of $18 \mathrm{~S}$ rRNA sequence complementarity to mRNA 5' UTRs and its implications for eukaryotic gene translation regulation. Nucleic Acids Res., 41 (16): 7625-7634. https://doi.org/10.1093/nar/gkt548.

Patarnello, T.; Bargelloni, L.; Caldara, F. and Colombo, L. (1993). Mitochondrial DNA sequence variation in the European sea bass, Dicentrarchus labrax L. (Serranidae): evidence of differential haplotype distribution in natural and farmed populations. Mol. Mar. Biol. Biotechnol., 2 (6): 333-337.

Paul, B. (2001). ITS region of the rDNA of Pythium longandrum, a new species; its taxonomy and its comparison with related species. FEMS Microbiol. Lett., 202 (2): 239-242. https://doi.org/10.1371/journal.pone.0025081.

Puillandre, N.; Lambert, A.; Brouillet, S. and Achaz, G. (2012). ABGD, Automatic Barcode Gap Discovery for primary species delimitation. Mol. Ecol., 21 (8): 1864-1877. https://doi.org/10.1111/j.1365-294X.2011.05239.x.

Šlapeta, J.; Moreira, D. and López-García, P. (2005). The extent of protist diversity: insights from molecular ecology of freshwater eukaryotes. Proc. R. Soc. Lond., Ser. B: Biol. Sci., 272 (1576): 2073-2081.

Smith, M. A.; Fisher, B. L. and Hebert, P. D. (2005). DNA barcoding for effective biodiversity assessment of a hyperdiverse arthropod group: the ants of Madagascar. Philos. Trans. R. Soc. Lond., B, Biol. Sci., 360 (1462): 18251834. https://doi.org/10.1098/rstb.2005.1714. 
Stern, R. F.; Andersen, R. A.; Jameson, I.; Küpper, F. C.; Coffroth, M.-A.; Vaulot, D.; Le Gall, F.; Veron, B.; Brand, J. J. and Skelton, H. (2012). Evaluating the ribosomal internal transcribed spacer (ITS) as a candidate dinoflagellate $\begin{array}{lllll}\text { barcode marker. PLoS One, } 7 & \text { (8): } & \text { e42780. }\end{array}$ https://doi.org/10.1371/journal.pone.0042780.

Tahir, A.; Hussain, F.; Ahmed, N.; Ghorbani, A. and Jamil, A. (2018). Assessing universality of DNA barcoding in geographically isolated selected desert medicinal species of Fabaceae and Poaceae. PeerJ, 6: e4499. https://doi.org/10.7717/peerj.4499.

Tsai, L. C.; Huang, M. T.; Hsiao, C. T.; Lin, C. Y. A.; Chen, S. J.; Lee, J. C.I. and Hsieh, H.-M. (2007). Species identification of animal specimens by cytochrome b gene. Forensic Sci. J., 6 (1): 63-6.

Vandamme, S. G.; Griffiths, A. M.; Taylor, S. A.; Di Muri, C.; Hankard, E. A.; Towne, J. A.; Watson, M. and Mariani, S. (2016). Sushi barcoding in the UK: another kettle of fish. PeerJ, 4: e1891. https://doi.org/0.7717/peerj.1891.

Vences, M.; Thomas, M.; Bonett, R. M. and Vieites, D. R. (2005). Deciphering amphibian diversity through DNA barcoding: chances and challenges. Philos. Trans. R. Soc. Lond. B Biol. Sci., 360 (1462): 1859-1868. 1859-1868. 10.1098/rstb.2005.1717.

Wang, W.; Ma, C.; Chen, W.; Zhang, H.; Kang, W.; Ni, Y. and Ma, L. (2017). Population genetic diversity of Chinese sea bass (Lateolabrax maculatus) from southeast coastal regions of China based on mitochondrial COI gene sequences. Biochem. Syst. Ecol., 71: 114-120. https://doi.org/10.1016/j.bse.2017.01.002.

Wang, X. C.; Liu, C.; Huang, L.; Bengtsson-Palme, J.; Chen, H.; Zhang, J. H.; Cai, D. and Li, J. Q. (2015). ITS 1: a DNA barcode better than ITS 2 in eukaryotes? Mol. Ecol. Resour., 15 (3): 573-586. https://doi.org/10.1111/1755-0998.12325.

Ward, R. D.; Hanner, R. and Hebert, P. D. (2009). The campaign to DNA barcode all fishes, FISH-BOL. J. Fish Biol., 74 (2): 329-356. https://doi.org/10.1111/j.1095-8649.2008.02080.x.

Ward, R. D.; Zemlak, T. S.; Innes, B. H.; Last, P. R. and Hebert, P. D. (2005). DNA barcoding Australia's fish species. Philos. Trans. R. Soc. Lond. B Biol. Sci., 360 (1462): 1847-1857. https://10.1098/rstb.2005.1716.

Waugh, J. (2007). DNA barcoding in animal species: progress, potential and pitfalls. Bioessays, 29 (2): 188-197. https://doi.org/10.1002/bies.20529.

White, T. J.; Bruns, T.; Lee, S. and Taylor, J. (1990). Amplification and direct sequencing of fungal ribosomal RNA genes for phylogenetics. In PCR Protocols: a Guide to Methods and Applications, eds. M. A. Innis, D. H. Gelfand, J. J. Snisky and T. J. White, 315-322. NY: Academic Press.

Whitehead, P. J. P.; Bauchot, M.; Hureau, J.; Nielsen, J. and Tortonese, E. (1986). Fishes of the North-eastern Atlantic and the Mediterranean. Paris, France: UNESCO.

$\mathrm{Xu}$, J. (2005). The inheritance of organelle genes and genomes: patterns and mechanisms. Genome, 48 (6): 951-958. https://doi.org/10.1139/g05-082.

Yao, H.; Song, J.; Liu, C.; Luo, K.; Han, J.; Li, Y.; Pang, X.; Xu, H.; Zhu, Y. and Xiao, P. (2010). Use of ITS2 region as the universal DNA barcode for plants $\begin{array}{lllll}\text { and animals. PLoS One, } & \text { (10): } 13102 .\end{array}$ https://doi.org/10.1371/journal.pone.0013102.

Zhan, A.; He, S.; Brown, E. A.; Chain, F. J.; Therriault, T. W.; Abbott, C. L.; Heath, D. D.; Cristescu, M. E. and MacIsaac, H. J. (2014). Reproducibility of pyrosequencing data for biodiversity assessment in complex communities. 
Methods Ecol. Evol., 5 (9): 881-890. https://doi.org/10.1111/2041210X.12230.

Zhang, A.; Sikes, D.; Muster, C. and Li, S. (2008). Inferring species membership using DNA sequences with back-propagation neural networks. Syst. Biol., 57 (2): 202-215. https://doi.org/10.1080/10635150802032982.

Zhang, J.; Kapli, P.; Pavlidis, P. and Stamatakis, A. (2013). A general species delimitation method with applications to phylogenetic placements. $\begin{array}{llll}\text { Bioinformatics, } & 29 & \text { (22): }\end{array}$ https://doi.org/10.1093/bioinformatics/btt499.

\section{ARABIC SUMMARY}

التعريف الجزيئي المقارن لجنس Dicentrarchus باستخدام جينات الميتوكوندريا ومنطقة ITS

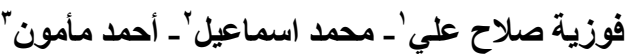

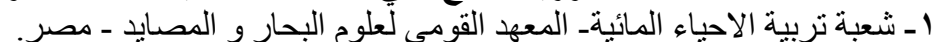

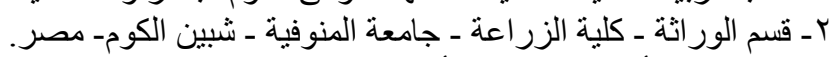

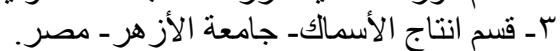

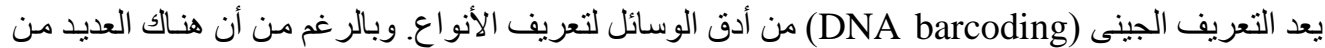

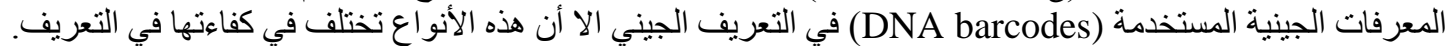

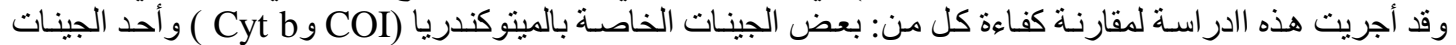

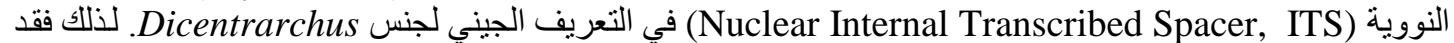

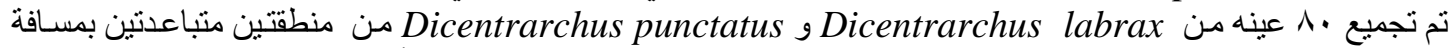

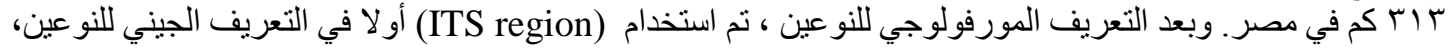

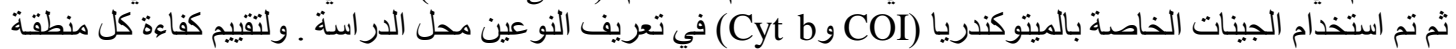

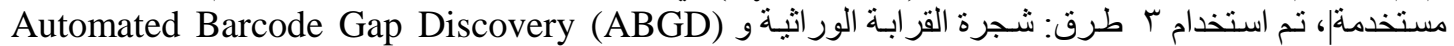

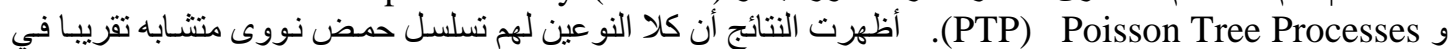

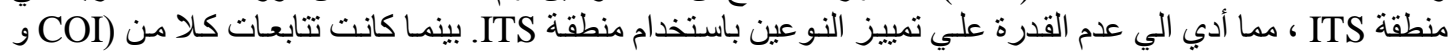
(Cyt b

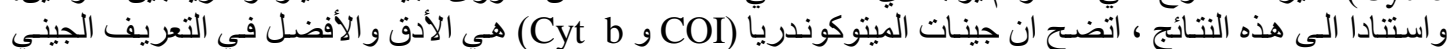

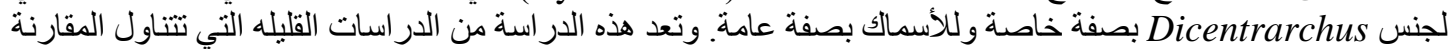
بين كفاءة الانو اع المختلفة للتعريف الجينى. 